\title{
Exploring intrinsic, instrumental, and relational values for sustainable management of social-ecological systems
}

\author{
Paola Arias-Arévalo $^{1,2}$, Berta Martín-López ${ }^{3}$ and Erik Gómez-Baggethun $^{4,5}$
}

\begin{abstract}
The values (i.e., importance) that people place on ecosystems have been identified as a crucial dimension of sustainable management of social-ecological systems. Recently, the call for integrating plural values of ecosystems beyond intrinsic and instrumental values has prompted the notion of "relational values." With the aim of contributing to environmental management, we assess the environmental motivations (i.e., egoistic, biospheric, altruistic) and values that people attribute to the ecosystems of the mid-upper stream of the Otún River watershed, central Andes, Colombia. We analyzed 589 questionnaires that were collected in urban and rural areas of the Otún River watershed using the nonparametric Mann-Whitney U test and logistic regressions. We found salient biospheric motivations and the attribution of plural values (i.e., intrinsic, relational, and instrumental) to the ecosystems of the mid-upper stream of the Otún River watershed. Particularly, relational values were the most frequently mentioned value domain. Further, our results showed that environmental motivations and socioeconomic factors are associated with the expression of different value domains. We found negative associations between egoistic motivations and intrinsic values and between rural respondents and instrumental values. We found positive associations between altruistic motivations and relational values and between rural respondents and both intrinsic and relational values. In light of our results, we argue that intrinsic, instrumental, and relational values coexist in people's narratives about the importance of ecosystems. Plural valuation approaches could be enhanced by differentiating relational from instrumental values and by expressing them in nonmonetary terms. We argue that multiple values of ecosystems expressed by rural and urban societies should be included in environmental management to tackle social conflicts and consider the diverse needs and interests of different social actors.
\end{abstract}

Key Words: ecosystem services valuation; environmental ethics; environmental management; environmental motivations; environmental values; transcendental values; value pluralism; watersheds

\section{INTRODUCTION}

Ecosystems provide vital ecosystem services to humans such as freshwater, energy, food, climate regulation, hydrological regulation, recreation, and aesthetic experiences (Millennium Ecosystem Assessment 2005). At the same time, human decisions and behaviors toward ecosystems influence ecosystems' capacity to supply ecosystem services (Daily et al. 2009). Human decisions and behaviors toward ecosystems are also determined by the multiples ways in which nature, ecosystems, or ecosystems services are important for individuals or social groups (Ives and Kendal 2014, Jones et al. 2016, Pascual et al. 2017, Arias-Arévalo et al. 2018).

The importance that people place on ecosystems and ecosystem services has been identified as a crucial dimension of sustainable management of social-ecological systems (Ostrom 2009). However, the study of values, and other human cognitions, has been poorly addressed by the research on social-ecological systems (Jones et al. 2016) and environmental management (Floress et al. 2015, Castro et al. 2016). Particularly, in the scientific field of ecosystem services, monetary valuation methods have received more attention than other valuation methods (Abson et al. 2014, Gómez-Baggethun and Martín-López 2015). Focusing only on monetary valuation emphasizes instrumental values while ignoring intrinsic and relational values (AriasArévalo et al. 2018).
Exploring plural values beyond instrumental values is gaining momentum in social-ecological systems and ecosystem services research (Chan et al. 2016, Kenter 2016a, Jacobs et al. 2016, Jones et al. 2016, Pascual et al. 2017, Arias-Arévalo et al. 2018). Instrumental values represent the value of ecosystems as merely means to an end and are often measured in monetary terms. By contrast, intrinsic values refer to the value of ecosystems as ends to themselves and are often represented as moral duties (AriasArévalo et al. 2018). The instrumental-intrinsic dichotomy has guided decisions about environmental management by either fostering market-based conservation approaches such as payments for ecosystem services or prompting the conservation of protected areas without any human intervention (Spash 2013, Anguelovski and Martínez Alier 2014, Martín-López and Montes 2015).

In recent years, ecosystem services valuation scholars have adhered to value pluralism: the recognition of different and often conflicting value domains that are neither reducible to each other nor to some ultimate value (Gómez-Baggethun and MartínLópez 2015, Jacobs et al. 2016, Kenter 2016a, Pascual et al. 2017, Arias-Arévalo et al. 2018). The spectrum of ecosystems valuation has broadened through the integration of relational values, which are those concerns associated with relationships and responsibilities between people or between nature and people (Chan et al. 2016). Examples of relational values include the

${ }^{1}$ Department of Economics, Faculty of Social and Economic Sciences, Universidad del Valle, Cali, Colombia, ${ }^{2}$ Institute of Environmental Science and Technology, Universitat Autònoma de Barcelona, Barcelona, Spain, ${ }^{3}$ Institute for Ethics and Transdisciplinary Sustainability Research, Faculty of Sustainability, Leuphana University of Lüneburg, Lüneburg, Germany, ${ }^{4}$ Department of International Environment and Development Studies, Norwegian University of Life Sciences, Ås, Norway, ${ }^{5}$ Norwegian Institute for Nature Research - NINA, Oslo, Norway 
ecological conditions ensuring the preservation of life on Earth, the social conditions for maintaining harmonic human-nature relationships (e.g., sacred and cultural values), or the experiences and entities necessary for cultivating the notion of a "good" life (e.g., aesthetic appreciation or cognitive development in naturebased contexts; Chan et al. 2016, Muraca 2016, Tadaki et al. 2017, Arias-Arévalo et al. 2018). See Box 1 for definitions.

\section{Box 1: Definitions of relevant concepts}

Altruistic motivations: Principles embracing concerns toward other humans (e.g., social justice).

Anthropocentrism: Human-centered system of values; the importance of entities for serving human beings and their purposes.

Articulated values: Concrete expressions of value domains stemming from valuation processes.

Biospheric motivations: Principles embracing concerns about nonhuman species and the biosphere (e.g., unity with nature).

Ecocentrism: System of values oriented to both living and nonliving systems.

Egoistic motivations: Principles embracing the maximization of individual gain (e.g., social power).

Instrumental value: The value of an entity as merely a means to an end.

Interests: Stakes at play in decisions contexts, which are influenced by motivations, values, and beliefs.

Intrinsic value: The value of nature, ecosystems, or life as ends in themselves, irrespective of their utility to humans.

Motivations: Stable principles that guide human judgments and action.

Pluralistic valuations of ecosystems: The process of analyzing, assessing, or understanding the multiple ways in which ecosystems and ecosystem services are important for people and how these multiples ways of importance are related (e.g., coexistences, synergies, trade-offs).

Relational values: The importance attributed to meaningful relations and responsibilities between humans and between humans and nature.

Value domain: A broad notion of the importance that people attribute to ecosystems, emerging from the diverse ways in which people engage with nature.

Value pluralism: An axiological position that recognizes different and often conflicting value domains that are neither reducible to each other nor to some ultimate value.

Values: Multiple ways in which nature, ecosystems, or ecosystems services are important for individuals or social groups.
Under this value pluralism approach, scholars have called for the integration of multiple disciplines as well as qualitative and quantitative methods in ecosystem services valuation (Kenter 2016a, Tadaki et al. 2017, Jacobs et al. 2018). For instance, recent research has demonstrated the benefits of integrating environmental psychology and valuation. In doing so, motivations, also known as orientations (de Groot and Steg 2008, 2010, Steg et al. 2011), are considered to be key factors determining environmental values (Kenter 2016b, Raymond and Kenter 2016). Scholars have quantitatively addressed three major motivations that influence environmental attitudes and behavior: egoistic, altruistic, and biospheric (de Groot and Steg 2008, 2010, Steg et al. 2011). Whereas egoistic motivations give priority to the maximization of individual gain, altruistic motivations embrace concerns toward other humans, and biospheric motivations extend these concerns to nonhuman species and the biosphere. See Box 1 for definitions.

Understanding the plural values that people attribute to ecosystems is a critical research priority toward the sustainable management of ecosystems. Pluralistic valuations may aid in: (1) understanding the coupled nature of social-ecological systems, offering new intervention points (Jones et al. 2016); (2) framing values as indirect or direct drivers of change (Jones et al. 2016); (3) aligning management interventions with people's values (Ives and Kendal 2014, Jones et al. 2016); and (4) identifying consensual and conflicting values associated with management approaches (Ives and Kendal 2014, Jacobs et al. 2016, Jones et al. 2016).

Here, our main objective is to assess the environmental motivations and values that people attribute to the ecosystems of the mid-upper stream of the Otún River watershed, central Andes, Colombia with the aim of informing environmental management. Specifically, we aim to: (1) examine the environmental motivations, i.e., egoistic, biospheric, and altruistic, of the inhabitants of the Otún River watershed; (2) assess the intrinsic, relational, and instrumental values by which rural and urban people attribute importance to the ecosystems of the watershed; and (3) analyze how motivations and socioeconomic factors (e.g., residence area, education) influence the expression of values. We present the roadmap of this research (Fig. 1) by indicating how specific objectives relate to different disciplines and how they are addressed by using multiple analytical methods.

\section{STUDY AREA}

The Otún River watershed is located on the western slope of the central Andes in the state of Risaralda, Colombia, with an extension of $480.6 \mathrm{~km}^{2}$ (Fig. 2). The Otún River arises at $5200 \mathrm{~m}$ above sea level (a.s.1.) at the Ramsar Otún Lake Wetland Complex and flows into the Cauca River at $875 \mathrm{~m}$ a.s.l. (CARDER 2008). The Otún River watershed hosts 423,130 inhabitants, mainly distributed in the municipalities of Pereira $(55.3 \%)$ and Dosquebradas $(43.7 \%)$ and marginally in the municipalities of Santa Rosa de Cabal (0.9\%) and Marsella (0.1\%; CARDER 2017). The Otún River watershed has been considered a strategic conservation area because of the presence of ecosystems of high ecological value such as páramo (alpine tundra) and high Andean and sub-Andean forests (CARDER 2008). The Otún River supplies water to nearly 450,000 habitants, including urban inhabitants of Pereira and Dosquebradas living outside of the 
Fig. 1. Roadmap of the study, showing the link between specific objectives, disciplines, methods, and data analysis.

\begin{tabular}{|c|c|c|}
\hline Specific objectives & Integration of disciplines & Methods and Data Analysis \\
\hline $\begin{array}{l}\text { 1. Examine urban and rural } \\
\text { prioritization of environmental } \\
\text { motivations -egoistic, biospheric and } \\
\text { altruistic. }\end{array}$ & $\begin{array}{c}\text { A. Social and } \\
\text { environmental psychology } \\
\text { (de Groot \& Steg 2008, 2010) }\end{array}$ & $\begin{array}{l}\text { - Quantitative measurement of environmental motivations through } \\
\text { a survey. } \\
\text { - Reliability of environmental motivations through factor analysis } \\
\text { - Prioritization of motivations through means and standard } \\
\text { deviations of motivations ranking } \\
\text { - Differences in the prioritization of motivations between urban and } \\
\text { rural respondents through Mann-Whitney test }\end{array}$ \\
\hline $\begin{array}{l}\text { 2. Assess the intrinsic, relational and } \\
\text { instrumental values by which rural and } \\
\text { urban people attribute importance to } \\
\text { the ecosystems of the mid-upper } \\
\text { stream Otún watershed }\end{array}$ & $\begin{array}{l}\text { B. Environmental ethics } \\
\text { and ecological economics } \\
\text { perspectives on ecosystem } \\
\text { services valuation } \\
\text { (Chan et al. 2016, Jax et al. } \\
\text { 2013, Arias-Arévalo et. al. } \\
\text { 2018) } \\
\end{array}$ & $\begin{array}{l}\text { - Qualitative narrative approach: open-ended question about the } \\
\text { importance of ecosystems. } \\
\text { - Content analysis to classify } 20 \text { articulated values and } 3 \text { value } \\
\text { domains (i.e. intrinsic, instrumental, and relational). } \\
\text { - Differences in the frequency of value mention between urban and } \\
\text { rural respondents through Mann-Whitney test }\end{array}$ \\
\hline $\begin{array}{l}\text { 3. Analyze how motivations and } \\
\text { socioeconomic factors (e.g. residence } \\
\text { area, education) influence the } \\
\text { expression of environmental values. }\end{array}$ & Integration of $\mathbf{A}$ and $\mathbf{B}$ & $\begin{array}{l}\text { - Quantitative multivariate logistic regressions to evidence the } \\
\text { relationships between both socio-economic factors and } \\
\text { environmental motivations and the expression of value domains } \\
\text { - Calculation of Odds ratio (OR) to analyze effect of socio- } \\
\text { economic factors and environmental motivations on the } \\
\text { probability of expressing a value domain. } \\
\text { - Akaike information criterion to select final models }\end{array}$ \\
\hline
\end{tabular}

watershed boundaries (CARDER 2016). For management purposes, the Otún River watershed is divided into three main areas: upper, middle, and downstream areas (Fig. 2). Our research focuses on the mid-upper stream, which ranges from 1400 to 4800 $\mathrm{m}$ a.s.1. Nowadays, $86 \%$ of the total area of the mid-upper stream belongs to protected areas (e.g., Los Nevados National Natural Park, Santuario de Flora y Fauna Otún Quimbaya). Because of the conservation efforts developed since the late 1950s, the Otún River watershed is considered one of the best conserved watersheds of Colombia (CARDER 2016).

Urban and rural people have different relationships with the ecosystems of the mid-upper stream of the Otún River watershed. Rural people use rivers and water sources to supply freshwater for human consumption and productive activities. Some rural people develop agricultural activities aimed at commercialization and subsistence, whereas others provide ecotourism services to urban people (Rincón-Ruíz et al. 2014, CARDER 2016). Rural people view the territory as the space for the social and cultural reproduction of peasant culture (Ángel 2014). Rural people's relations with ecosystems are crucial for securing the provision of ecosystem services for urban people: freshwater, food production, recreation, tourism, education, and research (Rincón-Ruíz et al. 2014, CARDER 2016). Mobilization and cultural exchange between rural and urban inhabitants are prominent because urban centers and rural towns are geographically close (Fig. 2). For a summary of rural and urban actors in the mid-upper stream of the Otún River watershed see Table 1.

Since the 1940s, the management of the mid-upper stream of the Otún River watershed has mainly focused on biodiversity conservation and water provision for urban areas (Barragán and Valdés 2011). Nowadays, the most relevant management institutions are: the local public company (Aguas y Aguas de Pereira), the Regional Environmental Authority (Corporación Autónoma Regional de Risaralda [CARDER]), and the National Natural Parks Institution (Unidad Administrativa Especial del Sistema de Parques Nacionales Naturales [UAESPNN]). These institutions have developed conservation actions such as land purchases for ecosystems restoration, creation of protected areas, and the declaration of a buffer zone (areas above the water catchment) as an area for the conservation of water for human consumption (Law 36 of 1987; CARDER 1987).

The development of conservation programs has created conflicts and tensions between rural actors and management institutions because such programs have affected rural people's livelihoods (Barragán and Valdés 2011, Monsalve 2012, Rincón-Ruíz et al. 2014). Land purchases and the expansion of protected areas have caused rural migration. In the buffer zone, restrictions of agricultural activities have caused the shutdown of poultry and pork farms, which were an important source of employment in the area; transitional crop restrictions affected the cultivation of vegetables and medicinal plants aimed at subsistence and commercialization; and the prohibition of new housing developments increased both the density (number of people) per household and lease prices (Barragán and Valdés 2011).

Because of agricultural restrictions in the buffer zone, since 1999, ecotourism has been promoted by management institutions as an income source for some community-based environmental associations (Barragán and Valdés 2011). In 2013, an ecotourism management plan was formulated with the goal of promoting sustainable ecotourism and generating revenues for an extended population beyond the members of the community-based associations (UAESPNN 2013). Currently, a new environmental 
Table 1. Main actors of the mid-upper stream of the Otún River watershed, Colombia.

\begin{tabular}{|c|c|c|}
\hline Actor & Location & Description \\
\hline $\begin{array}{l}\text { Communal action boards (Juntas de Acción } \\
\text { Comunal) }\end{array}$ & Rural and urban & Civic society corporations aimed at resolving neighborhood problems \\
\hline Rural community aqueducts & Rural & Nonprofit community-based organizations aimed at rural water supply \\
\hline Community-based environmental associations & Rural & $\begin{array}{l}\text { Community-based organizations aimed at ecotourism services provision, } \\
\text { environmental education, ecosystems conservation, sustainable agriculture } \\
\text { projects, promotion of traditional local knowledge, social cohesion, and leadership } \\
\text { (e.g., Cooperativa Multiactiva Defensora del Medio Ambiente [COOMDEMA], } \\
\text { Soledad de Montaña, Yarumo Blanco, Civil Society Natural Reserves Danteros } \\
\text { and Santa María de la Loma, Red de Vecinos y Amigos del Río Otún [CORPO- } \\
\text { OTUN]) }\end{array}$ \\
\hline Ecotourism services organizations & Rural & $\begin{array}{l}\text { Rural people providing transportation, lodging, recreation, and food services (e.g., } \\
\text { Red de Prestadores de Servicios Turísticos de la Cuenca del Rio Otún - Red Otún) }\end{array}$ \\
\hline Representatives of productive sectors & Rural & $\begin{array}{l}\text { Representatives of productive sectors such as pork, poultry, cattle, onion, and } \\
\text { coffee }\end{array}$ \\
\hline Municipalities & Urban & $\begin{array}{l}\text { Political administrative organization at the municipality level that is in charge of } \\
\text { the management of public resources and the execution of development policies }\end{array}$ \\
\hline $\begin{array}{l}\text { National Parks (Unidad Administrativa Especial } \\
\text { del Sistema de Parques Nacionales Naturales } \\
\text { [UAESPNN]) }\end{array}$ & Rural and urban & Public institution managing the Natural National Parks System \\
\hline Public company (Aguas y Aguas de Pereira) & Urban & Provides water and sanitation services \\
\hline $\begin{array}{l}\text { Regional Environmental Authority } \\
\text { (Corporación Autónoma Regional de Risaralda } \\
\text { [CARDER]) }\end{array}$ & Urban & $\begin{array}{l}\text { Environmental authority at the regional area in charge of the execution of } \\
\text { environmental policies and projects }\end{array}$ \\
\hline
\end{tabular}

management plan of the Otún River watershed is being formulated (CARDER 2016). In this process, rural community associations still expressed concerns regarding: (1) the restriction of productive activities because of the expansion of conservation areas, (2) the effects of unsustainable tourism, and (3) the lack of income sources. In this new management plan, payment for ecosystem services has been considered as one of the programs that can address these rural concerns (CARDER 2016). The development of these plans could become an opportunity for the integration of rural interests in the management of the mid-upper stream of the Otún River watershed.

\section{METHODOLOGY}

\section{Sampling}

Direct face-to-face questionnaires were conducted in June and July 2014. A draft of the questionnaire was pretested in May 2014 and thereafter revised. A simple random sampling was applied to represent rural and urban households. Purposive sampling was then conducted to select sampling points that covered different urban (33 sample points) and rural (10 sample points) settlements (Fig. 2). Urban sample points covered neighborhoods of the urban centers of Pereira and Dosquebradas. Rural sample points comprised districts outside these urban centers. Some sample points were outside the watershed boundaries, but they were selected because they are located in areas where people also demand ecosystem services provided by the mid-upper stream of the Otún watershed, including water provision, recreation, and leisure. Six hundred individual questionnaires were conducted, of which 11 were excluded for being incomplete, leaving a final sample size of 589 questionnaires.

\section{Data collection}

The questionnaire consisted of four sections. The first section aimed to identify whether the respondent was suitable to fill out the survey (i.e., $>16$ years old and an inhabitant of the watershed or influencing areas). The second section addressed environmental motivations. Respondents were asked to rate the importance of different motivations as guiding principles for action on a nine-point scale, with -1 meaning "contrary to my life motivations," and from 0 "not at all important" to 7 "of supreme importance." We used de Groot and Steg's (2008) classification of environmental motivations. Egoistic motivation embraced the prioritization of "power," "influence," "ambition," "authority," and "wealth." Altruistic motivation prioritized aspects such as "world peace," "being helpful," "social justice," and "equality." Finally, biospheric motivation embraced the prioritization of "preventing pollution," "respecting the earth," "unity with nature," and "protecting the environment" (see Appendix 1 for a description of motivations' components). In the third section, an open-ended question was included to identify the values that respondents attributed to the mid-upper stream of the Otún River watershed: "Why do you think it is important to conserve the ecosystems and landscapes of the mid-upper stream of the Otún River watershed?" This open-ended question was applied because narrative approaches have been highlighted as suitable for capturing plural values (Klain et al. 2014, Tadaki et al. 2017, Jacobs et al. 2018). The final section included questions about the respondents' socioeconomic characteristics such as household income, education level, and labor status.

\section{Data analysis}

First, a factor analysis was applied to assess the level of internal consistency among environmental motivations. Factor analysis contributed to cluster motivation components (e.g., social justice, equality, world peace) into the theoretical groups of motivations (e.g., altruistic). Cronbach's alpha was used to measure the reliability (i.e., internal consistency) of each motivation cluster. Cronbach's alpha "describes the extent to which all the items in a test measure the same concept or construct" (Tavakol and Dennick 2011:53), and ranges from 0 and 1. Means and standard deviations of each motivation were estimated to identify the 
Fig. 2. Maps of the study area and sampling locations.
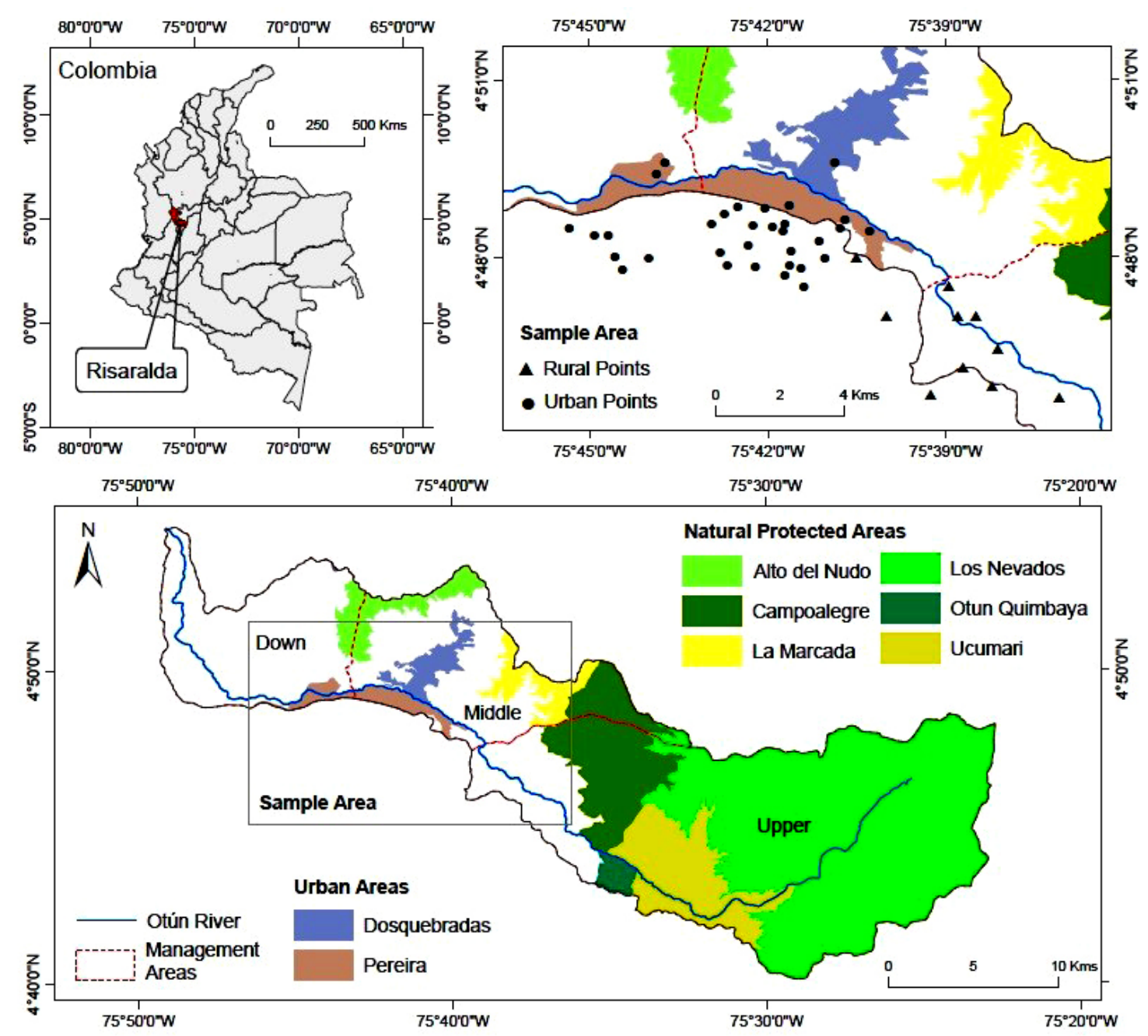

prioritization of environmental motivations in the total, urban, and rural respondents. Differences between rural and urban prioritization of motivations were explored using the MannWhitney U test.

To assess the values attributed by local people to the ecosystems of the mid-upper stream areas of the Otún River watershed, respondents' answers were coded through a content analysis. We coded the answers into three value domains (i.e., instrumental, intrinsic, and relational) and 20 articulated values, following the methods of Arias-Arévalo et al. (2018). Respondents' references to economic development and monetary benefits where coded as instrumental values. References to the importance of the ecosystems for securing life on earth was coded as intrinsic value, as were mentions of moral duties toward nonhuman entities. Relational values included references to ecological conditions ensuring ecosystems resilience, social conditions for maintaining harmonic human-nature relationships (e.g., identity, cultural heritage, symbolic and sacred values), and experiences and entities necessary for cultivating the notion of a "good" life (e.g., aesthetic and cognitive development values). Differences regarding the frequency of mention of environmental values between rural and urban respondents were explored using the Mann-Whitney U test.

Finally, three logistic regressions were performed to analyze the effect of environmental motivations and socioeconomic factors on the probability of expressing each value domain. Logistic regressions are used to test the hypothesis of whether a categorical outcome variable (e.g., $\mathrm{Y}=1$ if the respondent mentioned a value domain, $\mathrm{Y}=0$ if the contrary) is explained by other exposure variables (e.g., residence area; Peng et al. 2002). The odds ratio (OR) was calculated to measure the effect of exposures on the probability of expressing a value domain. When $\mathrm{OR}=1$, the exposure does not affect the odds of an outcome; OR $>1$ indicates that the exposure is associated with higher odds of an outcome; and $\mathrm{OR}<1$ indicates that the exposure is associated with lower odds of an outcome (Szumilas 2010). The exposure variables 
Table 2. Sample characteristics of respondents.

\begin{tabular}{|c|c|c|c|c|c|c|c|}
\hline \multirow[t]{2}{*}{ Variable } & \multirow[t]{2}{*}{ Definition } & \multicolumn{2}{|c|}{$\begin{array}{l}\text { Rural respondents } \\
\qquad N=224\end{array}$} & \multicolumn{2}{|c|}{$\begin{array}{l}\text { Urban respondents } \\
\qquad N=365\end{array}$} & \multicolumn{2}{|c|}{$\begin{array}{c}\text { Total respondents } \\
\qquad N=589\end{array}$} \\
\hline & & $N$ & $\%$ & $N$ & $\%$ & $N$ & $\%$ \\
\hline Education level & $\begin{array}{l}\text { None } \\
\text { Primary } \\
\text { High school } \\
\text { Technical school } \\
\text { University graduate } \\
\text { University postgraduate }\end{array}$ & $\begin{array}{c}6 \\
75 \\
98 \\
24 \\
19 \\
2\end{array}$ & $\begin{array}{c}2.7 \\
33.5 \\
43.8 \\
10.7 \\
8.5 \\
0.9\end{array}$ & $\begin{array}{c}2 \\
40 \\
136 \\
70 \\
104 \\
13\end{array}$ & $\begin{array}{c}0.5 \\
11.0 \\
37.3 \\
19.2 \\
28.5 \\
3.6\end{array}$ & $\begin{array}{c}8 \\
115 \\
294 \\
94 \\
123 \\
15\end{array}$ & $\begin{array}{c}1.4 \\
19.5 \\
39.7 \\
16.0 \\
20.9 \\
2.5\end{array}$ \\
\hline Gender & Female $=1$, Male $=0$ & 132 & 58.9 & 214 & 58.6 & 346 & 58.7 \\
\hline Marital status & Single $=1$, Otherwise $=0$ & 80 & 35.7 & 177 & 48.5 & 257 & 43.6 \\
\hline Labor status & Retired $=1$, Otherwise $=0$ & 8 & 3.6 & 16 & 4.4 & 24 & 4.1 \\
\hline Student & Student $=1$, Otherwise $=0$ & 23 & 10.3 & 56 & 15.3 & 79 & 13.4 \\
\hline Residence area & Rural $=1$, urban $=0$ & 224 & - & - & - & 224 & 38.0 \\
\hline \multirow{5}{*}{$\begin{array}{l}\text { Activities performed in } \\
\text { the mid-upper stream } \\
\text { of the Otún River } \\
\text { watershed }\end{array}$} & Aesthetic appreciation: yes $=1$, no $=0$ & 136 & 60.7 & 162 & 44.4 & 298 & 50.6 \\
\hline & Hiking $=1$, Otherwise $=0$ & 120 & 53.6 & 138 & 37.8 & 258 & 43.8 \\
\hline & Wildlife watching $=1$, Otherwise $=0$ & 115 & 51.3 & 110 & 30.1 & 225 & 38.2 \\
\hline & Swimming in the river $=1$, Otherwise $=0$ & 85 & 37.9 & 105 & 28.8 & 190 & 32.3 \\
\hline & Visiting waterfalls $=1$, Otherwise $=0$ & 94 & 42.0 & 72 & 19.7 & 166 & 28.2 \\
\hline
\end{tabular}

included environmental motivations, education level, marital status, labor status, residence area, and activities performed in the mid-upper stream of the Otún River watershed. Continuous variables (i.e., environmental motivations and education level) were re-escalated to a $0-1$ range before conducting logistic regressions. Final models were selected according to the Akaike information criterion (AIC; Akaike 1974).

\section{RESULTS}

\section{Sample characteristics}

Of the 589 completed surveys, $224(38.0 \%)$ were conducted in rural areas and $365(62.0 \%)$ in urban areas. The mean age of the sample respondents was $39 \mathrm{yr}$ (standard deviation $[\mathrm{SD}]=16.2$ $\mathrm{yr}$ ). The average monthly income was $\$ 185.9$ USD (SD $=\$ 332.7$; calculated based on the exchange rate for April 2016: \$3003 COP $=\$ 1$ USD). The average monthly income for rural respondents was $\$ 140.7$ ( $\mathrm{SD}=\$ 177.7$ ) and for urban respondents was $\$ 217.6$ $(\mathrm{SD}=\$ 220.8)$. The average number of activities performed in the mid-upper stream of the Otún River watershed for all respondents was $3.5(\mathrm{SD}=3.3)$; and $4.5(\mathrm{SD}=3.4)$ for rural and $2.8(\mathrm{SD}=$ 3.0) for urban respondents (Table 2).

\section{Environmental motivations}

Overall, respondents prioritized biospheric (mean $=6.5, \mathrm{SD}=$ $0.8)$ and altruistic $($ mean $=6.3, \mathrm{SD}=0.9)$ motivations over egoistic ones (mean $=4.2, \mathrm{SD}=1.4)$. Rural and urban respondents also presented this prioritization (Table 3). Mann-Whitney $U$ tests showed statistical differences for biospheric and altruistic motivations between rural and urban respondents. Cronbach's alpha revealed that biospheric and altruistic environmental motivations are internally consistent $(\alpha=0.81$ and 0.73 , respectively). The egoistic motivation showed lower internal consistency $(\alpha=0.64)$ than did the biospheric and altruistic motivations.

\section{Environmental values}

Respondents referred to a plurality of environmental values when they reflected on the importance of the mid-upper stream of the Otún River watershed (Table 4). Values in the domain of relational values were the most frequently mentioned by all respondents $(93.0 \%)$, followed by intrinsic values (40.7\%; Appendix 2). Instrumental values were only mentioned by $2.2 \%$ of respondents. The most widely mentioned articulated values in the total sample were the relational values of "subsistence and livelihoods" $(73.9 \%)$ and altruism $(37.0 \%)$. The third most mentioned articulated value was "moral duties toward biodiversity and ecosystems" $(34.0 \%)$ in the intrinsic values domain (Table 4).

Table 3. Prioritization of environmental motivations in total, rural, and urban respondents. SD = standard deviation.

\begin{tabular}{|c|c|c|c|c|c|c|c|}
\hline \multirow[b]{2}{*}{$\begin{array}{l}\text { Environmental } \\
\text { motivation }\end{array}$} & \multicolumn{2}{|c|}{ Total sample } & \multicolumn{2}{|c|}{ Rural } & \multicolumn{2}{|c|}{ Urban } & \multirow[b]{2}{*}{$\begin{array}{c}\text { Mann- } \\
\text { Whitney } \mathrm{U}^{\dagger}\end{array}$} \\
\hline & Mean & SD & Mean & SD & Mean & SD & \\
\hline Biospheric & 6.471 & 0.830 & 6.694 & 0.705 & 6.333 & 0.871 & $28,564 * *$ \\
\hline Altruistic & 6.315 & 0.877 & 6.569 & 0.669 & 6.159 & 0.951 & $29,898 * *$ \\
\hline Egoistic & 4.255 & 1.389 & 4.376 & 1.301 & 4.181 & 1.436 & 37,738 \\
\hline
\end{tabular}

We found statistically significant differences in the value domains mentioned by rural and urban respondents (Fig. 3). Respondents from rural areas referred to the domains of relational and intrinsic values more frequently than did urban respondents (relational: $\mathrm{U}=38,644, P=0.011$; intrinsic: $\mathrm{U}=37,721, P=0.064$; Fig. 3 ). Although the mention of the instrumental value domain was scarce in both sample groups, urban respondents referred more frequently to instrumental values than did rural respondents $(\mathrm{U}$ $=39,718, P=0.023$; Fig. 3 ). Appendix 2 presents the percentage of urban and rural respondents mentioning each articulated value.

\section{Influence of motivations, worldviews, and socioeconomic characteristics on environmental values}

The analysis of ORs in the logistic regressions showed that those respondents who gave a higher score to the egoistic motivation were less likely to express intrinsic values, whereas those who gave 
Table 4. Frequency and examples of respondents' articulated values when mentioning the importance of ecosystems in the mid-upper stream of the Otún River watershed.

\begin{tabular}{|c|c|c|c|c|}
\hline Value domain & Articulated value & $N$ & $\%$ & Example $^{\dagger}$ \\
\hline Instrumental & $\begin{array}{l}\text { Monetary benefits, } \\
\text { economic } \\
\text { development }\end{array}$ & 13 & 2.2 & $\begin{array}{l}\text { "If the Otún River watershed is not conserved, the water will run out and humans } \\
\text { depend on it. Onion crops is what people do as way of living, and if water runs out, } \\
\text { this will be harmful for people" (\#546R) }\end{array}$ \\
\hline \multirow[t]{2}{*}{ Intrinsic } & Life & 64 & 10.9 & $\begin{array}{l}\text { "The Otún River watershed should be conserved to maintain the life of people, plants, } \\
\text { and animals" (\#50U) }\end{array}$ \\
\hline & $\begin{array}{l}\text { Moral duties to } \\
\text { other organisms and } \\
\text { ecosystems }\end{array}$ & 200 & 34.0 & $\begin{array}{l}\text { "If we conserve the Otún River watershed, the trees, the river, and wildlife will be } \\
\text { preserved. They also have the right to have a clean home" (\#130U) }\end{array}$ \\
\hline \multirow[t]{17}{*}{ Relational } & Ecological resilience & 116 & 19.7 & $\begin{array}{l}\text { "The Otún River watershed ecological equilibrium has a big chance of being altered; } \\
\text { therefore, its conservation is vital for both the city and the surrounding rural } \\
\text { communities" (\#313U) }\end{array}$ \\
\hline & $\begin{array}{l}\text { Subsistence, } \\
\text { livelihoods }\end{array}$ & 449 & 76.2 & $\begin{array}{l}\text { "If we do not conserve the Otún River watershed we will not have water.... What is the } \\
\text { worth of money if there is no water or food?" (\#465R) }\end{array}$ \\
\hline & $\begin{array}{l}\text { Mental and physical } \\
\text { health }\end{array}$ & 134 & 22.8 & "Having good-quality water ensures good health and a good quality of life" (\#166U) \\
\hline & Identity & 14 & 2.4 & $\begin{array}{l}\text { "Our way of life comes from the Otún River watershed. The Otún River watershed is } \\
\text { the identity of all the people from Pereira" (\#308U) }\end{array}$ \\
\hline & Sense of place & 18 & 3.1 & $\begin{array}{l}\text { "If we don't take care of the Otún River watershed, we will lose all. If there is a day I } \\
\text { have to return to the city, that will be very hard for me. We have our jobs here. If we } \\
\text { don't take care of the Otún River watershed, who will take care of it? People from the } \\
\text { city will not come to take care of it" (\#463R) }\end{array}$ \\
\hline & Cultural heritage & 27 & 4.6 & $\begin{array}{l}\text { "The watershed with its natural beauty is the lung of the city; its beautiful landscapes } \\
\text { and its crystal water are a national heritage" (\#13U) }\end{array}$ \\
\hline & $\begin{array}{l}\text { Sacredness, religious } \\
\text { value }\end{array}$ & 14 & 2.4 & $\begin{array}{l}\text { "Our lives depend on the river; God gave it to us and it is our duty to take care of it" } \\
(\# 259 \mathrm{U})\end{array}$ \\
\hline & Symbolic value & 18 & 3.1 & $\begin{array}{l}\text { "The Otún River watershed is the soul and life of Pereira; this is a territory of peace } \\
\text { which exists in very few places" (\#415R) }\end{array}$ \\
\hline & Social cohesion & 3 & 0.5 & $\begin{array}{l}\text { "Everybody comes here, they have no fear of being robbed, if they are lost, local people } \\
\text { orient them. People are friendly and helpful" (\#471R) }\end{array}$ \\
\hline & General well-being & 53 & 9.0 & $\begin{array}{l}\text { "The Otún River watershed should be conserved because it is the basis of social well- } \\
\text { being" (\#97U) }\end{array}$ \\
\hline & $\begin{array}{l}\text { Meaningful } \\
\text { occupation }\end{array}$ & 8 & 1.4 & $\begin{array}{l}\text { "We must avoid pollution and avoid the river drying out, and thus avoid peasants' } \\
\text { unemployment" (\#506R) }\end{array}$ \\
\hline & Altruism & 218 & 37.0 & $\begin{array}{l}\text { "If we don't take care of the Otún River watershed, who will take care of it? Nature is } \\
\text { not ours, it is lent; nature is owned by our children. Downstream people drink water, } \\
\text { and here the river is born; we must take care of the water in benefit of the downstream } \\
\text { people" (\#265U) }\end{array}$ \\
\hline & $\begin{array}{l}\text { Environmental } \\
\text { justice }\end{array}$ & 6 & 1.0 & $\begin{array}{l}\text { "The Otún River watershed has been degraded because [people who have recently } \\
\text { arrived to the mid- and upper stream] abuse the watershed. The owner of the camping } \\
\text { zone abuses the river. The river has no owner but she [the camping zone owner] charges } \\
\text { fees for access. Local children used to go there to swim and now she denies them the } \\
\text { entrance." (\#475R) }\end{array}$ \\
\hline & Aesthetic & 54 & 9.2 & $\begin{array}{l}\text { "The Otún River watershed provides us with the opportunity to enjoy its landscape and } \\
\text { also have a near place to get in touch with nature" (\#172U) }\end{array}$ \\
\hline & Recreation, leisure & 24 & 4.1 & $\begin{array}{l}\text { "Because it is a place of nature in which we can recreate, rest, and have fun for a while" } \\
(\# 253 \mathrm{U})\end{array}$ \\
\hline & $\begin{array}{l}\text { Nature-based } \\
\text { tourism }\end{array}$ & 20 & 3.4 & $\begin{array}{l}\text { "The Otún River watershed is a tourism site for outsiders. It is the 'country club' for the } \\
\text { people from Pereira" }(\# 422 R)\end{array}$ \\
\hline & $\begin{array}{l}\text { Education and } \\
\text { cognitive } \\
\text { development }\end{array}$ & 15 & 2.5 & $\begin{array}{l}\text { "I arrived at the watershed as a blind man, the peasants taught me and I could open my } \\
\text { eyes... It is important to protect the Otún River watershed in order to teach our } \\
\text { children that we have beautiful sites, to teach them that the city is not everything we } \\
\text { have" (\#466R) }\end{array}$ \\
\hline
\end{tabular}

†We selected respondents' extracts that especially highlighted a value expression; however, the reader may infer in the same extract multiple articulated values. Parentheses indicate the questionnaire number and the respondent's residence area: $\mathrm{R}=$ rural, $\mathrm{U}=$ urban.

a higher score to altruistic motivations were more likely to express relational values (Table 5). With regard to socioeconomic factors, respondents living in rural areas were more likely to express intrinsic and relational values. By contrast, rural respondents were less likely to express instrumental values. A higher educational level was associated with a higher likelihood of expressing intrinsic and relational values. Further, a higher number of activities conducted by respondents in the mid-upper stream of the Otún River watershed was related to a higher likelihood of expressing relational values. 
Table 5. Results of logistic regressions that show the effect of motivations and socioeconomic factors on environmental values.

\begin{tabular}{|c|c|c|c|c|c|c|c|c|c|c|}
\hline \multirow[b]{3}{*}{ Factor } & \multirow[b]{3}{*}{ Category } & \multicolumn{9}{|c|}{ Environmental values } \\
\hline & & \multicolumn{3}{|c|}{ Instrumental } & \multicolumn{3}{|c|}{ Intrinsic } & \multicolumn{3}{|c|}{ Relational } \\
\hline & & Odds ratio & $\mathrm{SD}$ & $P$ & Odds ratio & $\mathrm{SD}$ & $P$ & Odds ratio & $\mathrm{SD}$ & $P$ \\
\hline & Intercept & 0.021 & 0.008 & $<0.0001$ & 0.353 & 0.164 & 0.025 & 0.859 & 0.703 & 0.852 \\
\hline \multirow{2}{*}{ Motivation } & Egoistic & & & & 0.339 & 0.168 & 0.029 & & & \\
\hline & Altruistic & & & & & & & 4.906 & 3.673 & 0.034 \\
\hline \multirow{7}{*}{$\begin{array}{l}\text { Socioeconomic } \\
\text { factor }\end{array}$} & Education level & & & & 4.064 & 2.068 & 0.006 & 8.592 & 8.226 & 0.025 \\
\hline & Single & & & & 1.502 & 0.276 & 0.027 & 0.477 & 0.167 & 0.035 \\
\hline & Student & 5.302 & 3.048 & 0.004 & & & & & & \\
\hline & Retired & & & & 0.360 & 0.203 & 0.069 & & & \\
\hline & Living in rural area & 0.148 & 0.155 & 0.069 & 1.736 & 0.342 & 0.005 & 2.308 & 1.029 & 0.061 \\
\hline & Number of activities & & & & & & & 6.227 & 5.819 & 0.050 \\
\hline & Aesthetic & & & & 1.461 & 0.260 & 0.033 & & & \\
\hline$N$ & & 589 & & & 589 & & & 589 & & \\
\hline Observed Y = 1 & & 13 & & & 240 & & & 548 & & \\
\hline Observed $\mathrm{Y}=0$ & & 576 & & & 349 & & & 41 & & \\
\hline \multirow[t]{6}{*}{ Regression tests } & & Value & SD & & Value & SD & & Value & SD & \\
\hline & Log-likelihood & 110.915 & & & 755.203 & & & 273.396 & & \\
\hline & Wald chi-square & 12.203 & 0.002 & & 36.671 & 0.000 & & 21.656 & 0.001 & \\
\hline & $\begin{array}{l}\text { Hosmer and } \\
\text { Lemeshow }\end{array}$ & 1.83 & 0.1762 & & 425.45 & 0.221 & & 406.36 & 0.4299 & \\
\hline & $\begin{array}{l}\text { Akaike information } \\
\text { criterion (AIC) }\end{array}$ & 116.915 & & & 769.203 & & & 285.396 & & \\
\hline & $\begin{array}{l}\text { Proportion of correct } \\
\text { estimated predictions } \\
(\%)\end{array}$ & 97.79 & & & 64.35 & & & 93.04 & & \\
\hline
\end{tabular}

Fig. 3. Frequency (\%) of the mention of value domains by urban and rural respondents. Asterisks indicate statistically significant differences between urban and rural respondents according to U Mann-Whitney tests: ${ }^{*} P<0.05, \dagger P<0.1$.

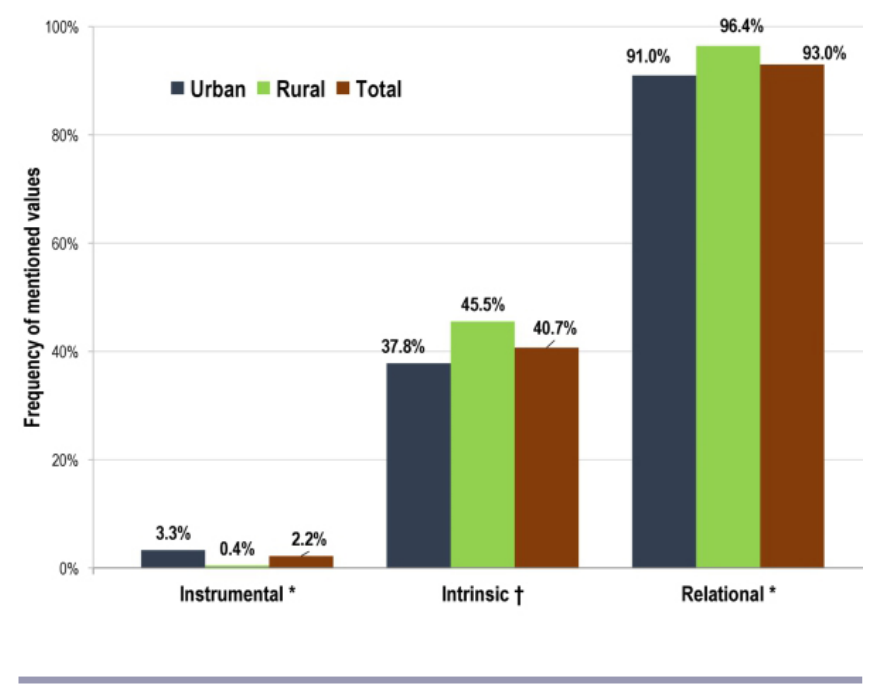

\section{DISCUSSION}

\section{Methodological contributions}

Here, we provide an example of how the integration of quantitative (i.e., environmental motivations measurement) and qualitative methods (i.e., narrative method) can contribute to the comprehensive valuation of ecosystems. One of the strengths of our methodological approach was the possibility of covering a large sample of respondents with different socioeconomic characteristics. This approach allows the application of a quantitative approach to address associations between values and both motivations and socioeconomic factors (Table 5). Further, our study demonstrates that the narrative method is a simple approach for capturing the diversity of environmental values (Tadaki et al. 2017, Jacobs et al. 2018).

\section{From the dichotomy of intrinsic vs. instrumental values to the} empirical recognition of plural values

Our results show that both urban and rural respondents attributed diverse values to the ecosystems of the mid-upper stream of the Otún River watershed, including intrinsic, relational, and instrumental values (Fig. 3, Table 4). One respondent mentioned that the ecosystems of the mid-upper stream of the Otún River watershed are important because "Water is indispensable for life on the planet: for humans, animals and plants... Having goodquality water ensures a good health and good quality of life. Additionally, many families depend economically on the watershed," (\#166U). In her narrative, the respondent mentioned intrinsic values (i.e., Earth life dependency on water, concerns toward plants and animals), relational values (i.e., health and quality of life), and instrumental values (i.e., economic dependency on the watershed). This holistic worldview contrasts with the dichotomy between intrinsic and instrumental values as the main argument for ecosystem conservation. People can endorse multiple values to the same ecosystem, indicating that the integration of value pluralism is necessary in environmental valuation. 
It is important to note that relational values was the domain most mentioned among urban and rural respondents (>90\%; Fig. 3). Within the domain of relational values, the most often mentioned articulated values were the subsistence value of water, mental and physical health, and the altruistic value embracing concerns to other human groups and future generations (Appendix 2). The concept of relational value has been recently emphasized in the academic discussion of ecosystem services assessments and valuations (Díaz et al. 2015, Chan et al. 2016, Pascual et al. 2017, Tadaki et al. 2017, Arias-Arevalo et al. 2018), although relational values have been addressed through the concepts of cultural ecosystem services (Chan et al. 2012, Daniel et al. 2012, Milcu et al. 2013) and socio-cultural valuations of ecosystem services (Oteros-Rozas et al. 2013, Iniesta-Arandia et al. 2014, Zagarola et al. 2014, Castro et al. 2016). Under the intrinsic-instrumental dichotomy, relational values have been conflated with instrumental values because of their anthropocentric nature (see Justus et al. 2009, Sagoff 2009). Such conflation implies that the aesthetic appreciation of the páramo ecosystem in the Otún River watershed (a relational value) can be substituted by the aesthetic appreciation of a painting of the same páramo. However, what is valued is the context-specific relation of aesthetic appreciation in that nature-based setting. This relation is not subject of exchange or commodification, and even its monetarization could be socially rejected. The classification of relational values as instrumental values has promoted the expression of relational values in monetary terms. For example, cultural ecosystem services research has focused on ecosystem services such as recreation and ecotourism that are easily quantified and monetized (Milcu et al. 2013). However, most cultural ecosystem services cannot be represented by monetary metrics because they represent deep human-nature relations (e.g., sacred and spiritual experiences, aesthetic enjoyment, and inspiration), and thus, their importance is expressed by relational values.

\section{The complex and placed-based nature of environmental values}

We have shown that environmental motivations and socioeconomic factors can influence the expression of environmental values in many ways (Table 5). A higher prioritization of the egoistic motivation was associated with a lower probability of expressing intrinsic values. This result is consistent with studies that have reported a negative effect of egoistic motivations on proenvironmental concerns (Steg et al. 2011, Raymond and Kenter 2016). By contrast, a higher prioritization of the altruistic motivation was associated with a higher probability of expressing relational values (Table 5). This result supports the notion that relational values embrace concerns about human relationships (Chan et al. 2016). For example, a rural respondent expressed, "Downstream people drink water, and here the river is born. We must take care of the water in benefit of the downstream people," (\#466R).

An interesting result is that respondents who visited the midupper stream for aesthetic appreciation were more likely to express intrinsic values (Table 5). Recently, Piccolo (2017) raised the question of "how relational and intrinsic values coexist." Our results provide empirical insights that relational and intrinsic values can emerge in intricate relationships. The aesthetic appreciation (relational value) of ecosystems is an anthropocentric activity. However, in our study this activity was positively related to the expression of intrinsic values (Table 5).
Similarly, Winter (2007) found that some respondents express spiritual (a relational value) and intrinsic values together.

We also found that people living in rural areas were more likely to attribute intrinsic and relational values, and less likely to attribute instrumental values, to the ecosystems of the mid- and upper stream of the Otún River watershed (Table 5). This result contrasts with those of previous studies, which have attributed higher proenvironmental concerns to urban than to rural people (e.g., Van Liere and Dunlap 1980, Arcury and Christianson 1993). Scholars have argued that rural people have more economic dependence on natural resources, and thus, more often express instrumental values (Huddart-Kennedy et al. 2009). Instead, we support the view that the strong connection of rural people with ecosystems, in terms of their cultural relations and their material dependence on ecosystems (Martínez-Alier 2002, Anguelovski and Martínez Alier 2014) can explain why they primarily express the importance of ecosystems in terms of relational and intrinsic values.

It is important to mention that although relative differences were found between rural and urban respondents, both samples presented the same pattern in the prioritization of environmental motivations, i.e., they prioritized biospheric and altruistic motivations over egoistic ones (Table 3). Additionally, both groups mentioned relational values and intrinsic values more frequently than instrumental values (Fig. 3). The identification of such common ground of agreement is essential for environmental management (Ives and Kendal 2014, Jones et al. 2016).

\section{Insights for environmental management}

Scholars have stressed the importance of analyzing public motivations for designing environmental policies (Steg et al. 2005, 2011, Ives and Kendal et al. 2014, Jones et al. 2016). Biospheric and altruistic motivations have shown to be positively associated with the social acceptance of environmental policies (Steg et al. 2005, 2011). Although conflicts and tensions have been reported between rural actors and management institutions in the midupper stream of the Otún River watershed (Barragán and Valdés 2011, Monsalve 2012, Rincón-Ruíz et al. 2014), our results suggest that these do not result from the clash of antienvironmental motivations: rural people prioritized biospheric and altruistic motivations over egoistic ones (Table 3). In the last decades, rural actors have supported conservation goals through their engagement in environmental community-based associations (Monsalve 2012). Furthermore, in the ecotourism management plan (UAESPNN 2013) and the new management plan of the Otún River watershed (CARDER 2016), the main goals of rural actors have been the generation of income sources and the promotion of the peasant culture while conserving ecosystems. However, during the last decades, the management of the Otún River watershed has emphasized the provision of water for urban areas, which emphasized a subsistence value for urban people (Barragán and Valdés 2011, Monsalve 2012, Rincón-Ruíz et al. 2014). Our research shows the need to include rural people in environmental management because of their concern for other relational values. Precisely, the environmental problems that rural people identified in the Otún watershed management plan (CARDER 2016) embrace relational values: restriction of productive activities (values of subsistence and 
livelihoods, meaningful occupation), loss of local ecological knowledge (values of cultural heritage and cognitive development), and loss of sense of place and identity (sense of place and identity values). Our results show that environmental management conflicts can emerge due to weak integration of the relational values of rural people in environmental management.

Environmental management can rely on a pluralistic valuation approach such as the one developed here, aimed at identifying those values that are outside current management objectives. These values can become new management objectives that may contribute to aligning environmental policies with people's values and thus minimize social conflicts (Ives and Kendal 2014, Jones et al. 2016). Additionally, management institutions can foster approaches such as the management plan of the UNESCO World Heritage Coffee Cultural Landscape (Ministerio de Cultura 2011, Barbero 2012), which covers some mid-stream areas of the Otún River watershed. The plan focuses on cultural values and also integrates environmental and economic objectives while promoting relational values (e.g., environmental sustainable coffee production, promotion of social and institutional networks, conservation of architectural heritage and local ecological knowledge). Finally, the development of a program of payments for ecosystem services in the mid-upper stream of the Otún River watershed, targeting the relational values of rural people, could present a way to integrate the salient biospheric and altruistic motivations. Local institutions and norms relying on such motivations and relational values could be the basis for such programs instead of focusing merely on monetary incentives (Kerr et al. 2014). The integration of relational values in the design of payment for ecosystem services may result in more effective conservation programs (Chan et al. 2016) and also in fairer ones because they may recognize the multiple ways in which the environment is important for multiple social actors.

Responses to this article can be read online at: http://www.ecologyandsociety.org/issues/responses. $\mathrm{php} / 9812$

\footnotetext{
Acknowledgments:

Paola Arias-Arévalo received funding from the Colombian Administrative Department of Science, Technology and InnovationColciencias (Convocatoria 529-2011) and from the Program of International Studies Commission of the Universidad del Valle, Colombia. Erik Gómez-Baggethun received partial funding from the talent development program of the Norwegian University of Life Sciences. Thanks are due to Julián Zúñiga-Barragán and the members of the research incubator on "Environmental economics and natural resources" of the Universidad Tecnologica de Pereira, Colombia, i.e., Jhon Jairo Arias, Luisa Fernanda Arango Londoño, Ana Maria Buitrago Ramirez, Derleycy García Mejía and Jhoan Sebastian Marin Agudelo, for the invaluable fieldwork support. We are also grateful to Tom Do and Kathleen Curtin for English language revisions, and to three anonymous referees for discussions and helpful comments on earlier versions of the manuscript. Many thanks to the people of the Otun River watershed who kindly and disinterestedly responded to the questionnaire used in this research.
}

\section{LITERATURE CITED}

Abson, D. J., H. von Wehrden, S. Baumgärtner, J. Fischer, J. Hanspach, W. Härdtle, H. Heinrichs, A. M. Klein, D. J. Lang, P. Martens, and D. Walmsley. 2014. Ecosystem services as a boundary object for sustainability. Ecological Economics 103:29-37. https://doi.org/10.1016/j.ecolecon.2014.04.012

Akaike, H. 1974. A new look at the statistical model identification. IEEE Transactions on Automatic Control 19(6):716-723. http:// dx.doi.org/10.1109/TAC.1974.1100705

Ángel, V. 2014. Otún en colores: memoria e historia social en la cuenca media-alta del Río Otún. Instituto Municipal de Cultura y Fomento al Turismo, Pereira, Colombia.

Anguelovski, I., and J. Martínez-Alier. 2014. The 'environmentalism of the poor' revisited: territory and place in disconnected glocal struggles. Ecological Economics 102:167-176. http://dx.doi. org/10.1016/j.ecolecon.2014.04.005

Arcury, T. A., and E. H. Christianson. 1993. Rural-urban differences in environmental knowledge and actions. Journal of Environmental Education 25(1):19-25. http://dx.doi. org/10.1080/00958964.1993.9941940

Arias-Arévalo, P., E. Gómez-Baggethun, B. Martín-López, and M. Pérez-Rincón. 2018. Widening the evaluative space for ecosystem services: a taxonomy of plural values and valuation methods. Environmental Values, in press.

Barbero, V. I. 2012. Paisaje cultural cafetero: paisaje productivo para el mundo en el marco de las políticas de desarrollo local. Labor and Engenho 6(2):39-51.

Barragán, J. M., and R. D. Valdés. 2011. Lineamientos de participación comunitaria en el manejo de un área protegida, como alternativa de manejo incluyente del territorio: una aproximación desde el conflicto ambiental por la conservación de la naturaleza en la cuenca media del Río Otún. Universidad Tecnológica de Pereira, Pereira, Colombia. [online] URL: http://hdl.handle.net/11059/2275

Castro, A. J., C. C. Vaughn, J. P. Julian, and M. García-Llorente. 2016. Social demand for ecosystem services and implications for watershed management. Journal of the American Water Resources Association 52(1):209-221. http://dx.doi.org/10.1111/1752-1688.12379

Chan, K. M. A., P. Balvanera, K. Benessaiah, M. Chapman, S. Díaz, E. Gómez-Baggethun, R. Gould, N. Hannahs, K. Jax, S. Klain, G. W. Luck, B. Martín-López, B. Muraca, B. Norton, K. Ott, U. Pascual, T. Satterfield, M. Tadaki, J. Taggart, and N. Turner. 2016. Opinion: Why protect nature? Rethinking values and the environment. Proceedings of the National Academy of Sciences 113(6):1462-1465. http://dx.doi.org/10.1073/pnas.1525002113

Corporación Autónoma Regional de Risaralda (CARDER). 1987. Acuerdo 036 of 1987: Por medio del cual se reglamentan acciones tendientes a conservar la calidad del agua del río Otún y garantizar su uso humano y doméstico. CARDER, Pereira, Colombia. [online] URL: http://www.carder.gov.co/app/webroot/ index.php/intradocuments/webDownload/acuerdo-036-de-1987

Corporación Autónoma Regional de Risaralda (CARDER). 2008. Plan de ordenación y manejo de la cuenca hidrográfica del Río Otún. CARDER, Pereira, Colombia. 
Corporación Autónoma Regional de Risaralda (CARDER). 2016. Ajuste al plan de ordenamiento y manejo de la cuenca del Río Otún. Fase de Aprestamiento. CARDER, Pereira, Colombia.

Corporación Autónoma Regional de Risaralda (CARDER). 2017. Ajuste plan de ordenación y manejo de la cuenca del Rio Otún fase de diagnóstico. Resumen ejecutivo. CARDER, Pereira, Colombia.

Daily, G. C., S. Polasky, J. Goldstein, P. M. Kareiva, H. A. Mooney, L. Pejchar, T. H. Ricketts, J. Salzman, and R. Shallenberger. 2009. Ecosystem services in decision making: time to deliver. Frontiers in Ecology and the Environment 7(1):21-28. http://dx.doi.org/10.1890/080025

Daniel, T. C., A. Muhar, A. Arnberger, O. Aznar, J. W. Boyd, K. M. A. Chan, R. Costanza, T. Elmqvist, C. G. Flint, P. H. Gobster, A. Grêt-Regamey, R. Lave, S. Muhar, M. Penker, R. G. Ribe, T. Schauppenlehner, T. Sikor, I. Soloviy, M. Spierenburg, K. Taczanowska, J. Tam, and A. von der Dunk. 2012. Contributions of cultural services to the ecosystem services agenda. Proceedings of the National Academy of Sciences 109(23):8812-8819. http:// dx.doi.org/10.1073/pnas. 1114773109

de Groot, J. I. M., and L. Steg. 2008. Value orientations to explain beliefs related to environmental significant behavior: how to measure egoistic, altruistic, and biospheric value orientations. Environment and Behavior 40(3):330-354. http://dx.doi. org/10.1177/0013916506297831

de Groot, J. I. M., and L. Steg. 2010. Relationships between value orientations, self-determined motivational types and proenvironmental behavioural intentions. Journal of Environmental Psychology 30(4):368-378. http://dx.doi.org/10.1016/j.jenvp.2010.04.002

Díaz, S., S. Demissew, J. Carabias, C. Joly, M. Lonsdale, N. Ash, A. Larigauderie, J. R. Adhikari, S. Arico, A. Báldi, A. Bartuska, I. A. Baste, A. Bilgin, E. Brondizio, K. M. A. Chan, V. E. Figueroa, A. Duraiappah, M. Fischer, R. Hill, T. Koetz, P. Leadley, P. Lyver, G. M. Mace, B. Martin-Lopez, M. Okumura, D. Pacheco, U. Pascual, E. S. Pérez, B. Reyers, E. Roth, O. Saito, R. J. Scholes, N. Sharma, H. Tallis, R. Thaman, R. Watson, T. Yahara, Z. A. Hamid, C. Akosim, Y. Al-Hafedh, R. Allahverdiyev, E. Amankwah, S. T. Asah, Z. Asfaw, G. Bartus, L. A. Brooks, J. Caillaux, G. Dalle, D. Darnaedi, A. Driver, G. Erpul, P. EscobarEyzaguirre, P. Failler, A. M. M. Fouda, B. Fu, H. Gundimeda, S. Hashimoto, F. Homer, S. Lavorel, G. Lichtenstein, W. A. Mala, W. Mandivenyi, P. Matczak, C. Mbizvo, M. Mehrdadi, J. P. Metzger, J. B. Mikissa, H. Moller, H. A. Mooney, P. Mumby, H. Nagendra, C. Nesshover, A. A. Oteng-Yeboah, G. Pataki, M. Roué, J. Rubis, M. Schultz, P. Smith, R. Sumaila, K. Takeuchi, S. Thomas, M. Verma, Y. Yeo-Chang, and D. Zlatanova. 2015. The IPBES conceptual framework - connecting nature and people. Current Opinion in Environmental Sustainability 14:1-16. http:// dx.doi.org/10.1016/j.cosust.2014.11.002

Floress, K., K. Akamani, K. E. Halvorsen, A. T. Kozich, and M. Davenport. 2015. The role of social science in successfully implementing watershed management strategies. Journal of Contemporary Water Research and Education 154(1):85-105. http://dx.doi.org/10.1111/j.1936-704X.2015.03189.x

Gómez-Baggethun, E., and B. Martín-López. 2015. Ecological economics perspectives on ecosystem services valuation. Pages
260-282 in J. Martínez-Alier and R. Muradian, editors. Handbook of ecological economics. Edward Elgar, Cheltenham, UK. http:// dx.doi.org/10.4337/9781783471416.00015

Huddart-Kennedy, E., T. M. Beckley, B. L. McFarlane, and S. Nadeau. 2009. Rural-urban differences in environmental concern in Canada. Rural Sociology 74(3):309-329.

Iniesta-Arandia, I., M. García-Llorente, P. A. Aguilera, C. Montes, and B. Martín-López. 2014. Socio-cultural valuation of ecosystem services: uncovering the links between values, drivers of change, and human well-being. Ecological Economics 108:36-48. http://dx.doi.org/10.1016/j.ecolecon.2014.09.028

Ives, C. D., and D. Kendal. 2014. The role of social values in the management of ecological systems. Journal of Environmental Management 144:67-72. http://dx.doi.org/10.1016/j.jenvman.2014.05.013

Jacobs, S., N. Dendoncker, B. Martín-López, D. N. Barton, E. Gomez-Baggethun, F. Boeraeve, F. L. McGrath, K. Vierikko, D. Geneletti, K. J. Sevecke, N. Pipart, E. Primmer, P. Mederly, S. Schmidt, A. Aragão, H. Baral, R. H. Bark, T. Briceno, D. Brogna, P. Cabral, R. De Vreese, C. Liquete, H. Mueller, K. S.-H. Peh, A. Phelan, A. R. Rincón, S. H. Rogers, F. Turkelboom, W. Van Reeth, B. T. van Zanten, H. K. Wam, and C.-L. Washbourne. 2016. A new valuation school: integrating diverse values of nature in resource and land use decisions. Ecosystem Services 22 (B):213-220. http://dx.doi.org/10.1016/j.ecoser.2016.11.007

Jacobs, S., B. Martín-López, D. N. Barton, R. Dunford, P. A. Harrison, E. Kelemen, H. Saarikoski, M. Termansen, M. GarcíaLlorente, E. Gómez-Baggethun, L. Kopperoinen, S. Luque, I. Palomo, J. A. Priess, G. M. Rusch, P. Tenerelli, F. Turkelboom, R. Demeyer, J. Hauck, H. Keune, and R. Smith. 2018. The means determine the end - pursuing integrated valuation in practice. Ecosystem Services, in press. https://doi.org/10.1016/j.ecoser.2017.07.011

Jax, K., D. Barton, K. Chan, R. de Groot, U. Doyle, U. Eser, C. Görg, E. Gómez-Baggethun, Y. Griewald, W. Haber, R. HainesYoung, U. Heink, T. Jahn, H. Joosten, L. Kerschbaumer, H. Korn, G. Luck, B. Matzdorf, B. Muraca, C. Neßhöver, B. Norton, K. Ott, M. Potschin, F. Rauschmayer, C. von Haaren, and S. Wichmann. 2013. Ecosystem services and ethics. Ecological Economics 93:260-268. https://doi.org/10.1016/j.ecolecon.2013.06.008

Jones, N. A., S. Shaw, H. Ross, K. Witt, and B. Pinner. 2016. The study of human values in understanding and managing socialecological systems. Ecology and Society 21(1):15. http://dx.doi. org/10.5751/ES-07977-210115

Justus, J., M. Colyvan, H. Regan, and L. Maguire. 2009. Buying into conservation: intrinsic versus instrumental value. Trends in Ecology and Evolution 24(4):187-191. http://dx.doi.org/10.1016/j. tree.2008.11.011

Kenter, J. O. 2016a. Editorial: Shared, plural and cultural values. Ecosystem Services 21(B):175-183. https://doi.org/10.1016/j. ecoser.2016.10.010

Kenter, J. O. 2016b. Integrating deliberative monetary valuation, systems modelling and participatory mapping to assess shared values of ecosystem services. Ecosystem Services 21(B):291-307. https://doi.org/10.1016/j.ecoser.2016.06.010 
Kerr, J. M., M. Vardhan, and R. Jindal. 2014. Incentives, conditionality and collective action in payment for environmental services. International Journal of the Commons 8(2):595-616. http://dx.doi.org/10.18352/ijc.438

Klain, S. C., T. A. Satterfield, and K. M. A. Chan. 2014. What matters and why? Ecosystem services and their bundled qualities. Ecological Economics 107: 310-320. http://dx.doi.org/10.1016/j. ecolecon.2014.09.003

Martín-López, B., and C. Montes. 2015. Restoring the human capacity for conserving biodiversity: a social-ecological approach. Sustainability Science 10(4):699-706. http://dx.doi. org/10.1007/s11625-014-0283-3

Martínez-Alier, J. 2002. The environmentalism of the poor: a study of ecological conflicts and valuation. Edward Elgar, Cheltenham, UK.

Milcu, A. I., J. Hanspach, D. Abson, and J. Fischer. 2013. Cultural ecosystem services: a literature review and prospects for future research. Ecology and Society 18(3):44. http://dx.doi.org/10.5751/ ES-05790-180344

Millennium Ecosystem Assessment. 2005. Ecosystems and human well-being: a framework for assessment. Island Press, Washington, D.C., USA.

Ministerio de Cultura. 2011. Paisaje cultural cafetero: un paisaje cultural productivo en permanente desarrollo. Ministerio de Cultura, Bogotá, Colombia. [online] URL: http://www.carder. gov.co/intradocuments/webDownload/aprestamiento-y-prospectiva

Monsalve, B. M. 2012. Participación social en el manejo de Áreas Naturales Protegidas (Risaralda). Universidad Tecnológica de Pereira, Pereira, Colombia. [online] URL: http://hdl.handle. net/11059/2902

Muraca, B. 2016. Re-appropriating the ecosystem services concept for a decolonization of 'nature.' Pages 143-156 in B. Bannon, editor. Nature and experience: phenomenology and the environment. Rowman and Littlefield International, London, UK.

Ostrom, E. 2009. A general framework for analyzing sustainability of social-ecological systems. Science 325 (5939):419-422. http://dx.doi.org/10.1126/science.1172133

Oteros-Rozas, E., B. Martín-López, J. A. González, T. Plieninger, C. A. López, and C. Montes. 2014. Socio-cultural valuation of ecosystem services in a transhumance social-ecological network. Regional Environmental Change 14(4):1269-1289. http://dx.doi. org/10.1007/s10113-013-0571-y

Pascual, U., P. Balvanera, S. Díaz, G. Pataki, E. Roth, M. Stenseke, R. T. Watson, E. B. Dessane, M. Islar, E. Kelemen, V. Maris, M. Quaas, S. M. Subramanian, H. Wittmer, A. Adlan, S. Ahn, Y. S. Al-Hafedh, E. Amankwah, S. T. Asah, P. Berry, A. Bilgin, S. J. Breslow, C. Bullock, D. Cáceres, H. Daly-Hassen, E. Figueroa, C. D. Golden, E. Gómez-Baggethun, D. GonzálezJiménez, J. Houdet, H. Keune, R. Kumar, K. Ma, P. H. May, A. Mead, P. O'Farrell, R. Pandit, W. Pengue, R. Pichis-Madruga, F. Popa, S. Preston, D. Pacheco-Balanza, H. Saarikoski, B. B. Strassburg, M. van den Belt, M. Verma, F. Wickson, N. Yagi.
2017. Valuing nature's contributions to people: the IPBES approach. Current Opinion in Environmental Sustainability 26-27:7-16. http://dx.doi.org/10.1016/j.cosust.2016.12.006

Peng, C.-Y. J., K. L. Lee, and G. M. Ingersoll. 2002. An introduction to logistic regression analysis and reporting. Journal of Educational Research 96(1):3-14. http://dx.doi. org/10.1080/00220670209598786

Piccolo, J. J. 2017. Intrinsic values in nature: objective good or simply half of an unhelpful dichotomy? Journal for Nature Conservation 37:8-11. https://doi.org/10.1016/j.jnc.2017.02.007

Raymond, C. M., and J. O. Kenter. 2016. Transcendental values and the valuation and management of ecosystem services. Ecosystem Services 21(B):241-257. https://doi.org/10.1016/j. ecoser.2016.07.018

Rincón-Ruíz, A., M. Echeverry-Duque, A. M. Piñeros, C. H. Tapia, A. David, P. Arias-Arévalo, and P. Zuluaga. 2014. Valoración integral de la biodiversidad y los servicios ecosistémicos: aspectos conceptuales y metodológicos. Instituto de Investigación de Recursos Biológicos Alexander von Humboldt (IAvH), Bogotá, Colombia. [online] URL: http://www.humboldt.org.co/ es/test/item/533-valoracion-integral-de-la-biodiversidad-y-los-serviciosecosistemicos

Sagoff, M. 2009. Intrinsic value: a reply to Justus et al. Trends in Ecology and Evolution 24(12):643. http://dx.doi.org/10.1016/j. tree.2009.07.005

Spash, C. L. 2013. The shallow or the deep ecological economics movement? Ecological Economics 93:351-362. https://doi. org/10.1016/j.ecolecon.2013.05.016

Steg, L., J. I. M. de Groot, L. Dreijerink, W. Abrahamse, and F. Siero. 2011. General antecedents of personal norms, policy acceptability, and intentions: the role of values, worldviews, and environmental concern. Society and Natural Resources 24 (4):349-367. http://dx.doi.org/10.1080/08941920903214116

Steg, L., L. Dreijerink, and W. Abrahamse. 2005. Factors influencing the acceptability of energy policies: a test of VBN theory. Journal of Environmental Psychology 25(4):415-425. http://dx.doi.org/10.1016/i.jenvp.2005.08.003

Szumilas, M. 2010. Explaining odds ratios. Journal of the Canadian Academy of Child and Adolescent Psychiatry 19 (3):227-229.

Tadaki, M., J. Sinner, and K. M. A. Chan. 2017. Making sense of environmental values: a typology of concepts. Ecology and Society 22(1):7. http://dx.doi.org/10.5751/ES-08999-220107

Tavakol, M., and R. Dennick. 2011. Making sense of Cronbach's alpha. International Journal of Medical Education 2:53-55. http:// dx.doi.org/10.5116/ijme.4dfb.8dfd

Unidad Administrativa Especial del Sistema de Parques Nacionales Naturales (UAESPNN). 2013. Plan estratégico para el ecoturismo en las áreas protegidas de la cuenca alta del Río Otún. Parques Nacionales Naturales de Colombia, Pereira, Colombia. [online] URL: http://www.parquesnacionales.gov.co/portal/wpcontent/uploads/2014/05/plan_estrategico ecoturismo_areas_protegidas cuenca alta rio.pdf 
Van Liere, K. D., and R. E. Dunlap. 1980. The social bases of environmental concern: a review of hypotheses, explanations and empirical evidence. Public Opinion Quarterly 44(2):181-197. https://doi.org/10.1086/268583

Winter, C. 2007. The intrinsic, instrumental and spiritual values of natural area visitors and the general public: a comparative study. Journal of Sustainable Tourism 15(6):599-614. http://dx. doi.org/10.2167/jost686.0

Zagarola, J.-P. A., C. B. Anderson, and J. R. Veteto. 2014. Perceiving Patagonia: an assessment of social values and perspectives regarding watershed ecosystem services and management in southern South America. Environmental Management 53(4):769-782. http://dx.doi.org/10.1007/s00267-014-0237-7 
Appendix 1. Factor analysis results for environmental motivations. (SD: standard deviation; $\alpha$ : Cronbach's alpha)

\begin{tabular}{|c|c|c|c|c|c|c|c|c|}
\hline \multirow{2}{*}{$\begin{array}{c}\text { Environmental } \\
\text { motivations }\end{array}$} & & & \multicolumn{2}{|c|}{ Total Sample } & \multicolumn{2}{|c|}{ Rural } & \multicolumn{2}{|c|}{ Urban } \\
\hline & & Factor & Mean & SD & Mean & SD & Mean & SD \\
\hline & & Loading & & & & & & \\
\hline Biospheric & Description & & 6.471 & 0.830 & 6.694 & 0.705 & 6.333 & 0.871 \\
\hline Preventing pollution & $\begin{array}{l}\text { Protecting natural } \\
\text { resources }\end{array}$ & 0.766 & 6.487 & 1.021 & 6.679 & 0.963 & 6.370 & 1.039 \\
\hline Respecting the earth & $\begin{array}{l}\text { Harmony with } \\
\text { other species }\end{array}$ & 0.830 & 6.495 & 1.013 & 6.703 & 0.874 & 6.367 & 1.070 \\
\hline Unity with nature & Fitting into nature & 0.799 & 6.385 & 1.143 & 6.671 & 0.891 & 6.209 & 1.242 \\
\hline $\begin{array}{l}\text { Protecting the } \\
\text { environment }\end{array}$ & Preserving nature & 0.784 & 6.515 & 0.997 & 6.723 & 0.855 & 6.388 & 1.057 \\
\hline Altruistic & & & 6.315 & 0.877 & 6.569 & 0.669 & 6.159 & 0.951 \\
\hline World peace & $\begin{array}{l}\text { Free of war and } \\
\text { conflict }\end{array}$ & 0.749 & 6.505 & 1.032 & 6.739 & 0.801 & 6.362 & 1.129 \\
\hline Helpful & $\begin{array}{l}\text { Working for the } \\
\text { welfare of others }\end{array}$ & 0.765 & 6.228 & 1.200 & 6.461 & 1.028 & 6.085 & 1.276 \\
\hline Social Justice & $\begin{array}{l}\text { Correcting } \\
\text { injustice, care for } \\
\text { the weak }\end{array}$ & 0.752 & 6.170 & 1.252 & 6.488 & 0.961 & 5.976 & 1.366 \\
\hline Equality & $\begin{array}{l}\text { Equal opportunity } \\
\text { for all }\end{array}$ & 0.697 & 6.357 & 1.248 & 6.589 & 0.924 & 6.214 & 1.393 \\
\hline Egoistic & & & 4.255 & 1.389 & 4.376 & 1.301 & 4.181 & 1.436 \\
\hline Social power & $\begin{array}{l}\text { Control over } \\
\text { others, dominance }\end{array}$ & 0.631 & 2.500 & 2.721 & 2.438 & 2.817 & 2.538 & 2.664 \\
\hline Influential & $\begin{array}{l}\text { Having an impact } \\
\text { on people and } \\
\text { events }\end{array}$ & 0.549 & 4.819 & 2.082 & 5.343 & 1.900 & 4.498 & 2.126 \\
\hline Ambition & $\begin{array}{l}\text { Hard-working, } \\
\text { aspiring }\end{array}$ & 0.502 & 5.454 & 2.065 & 5.652 & 2.116 & 5.333 & 2.026 \\
\hline Authority & $\begin{array}{l}\text { The right to lead } \\
\text { or command }\end{array}$ & 0.778 & 4.439 & 2.035 & 4.444 & 2.059 & 4.436 & 2.023 \\
\hline Wealth & $\begin{array}{l}\text { Material } \\
\text { possessions, } \\
\text { money }\end{array}$ & 0.716 & 4.065 & 1.977 & 4.004 & 1.916 & 4.102 & 2.015 \\
\hline
\end{tabular}


Appendix 2. Environmental values attributed to the mid- and upper-stream of the Otún River watershed

\begin{tabular}{|c|c|c|c|c|}
\hline Articulated values & $\begin{array}{c}\text { Urban } \\
\text { Respondents } \\
\text { (n) }\end{array}$ & $\%$ & $\begin{array}{c}\text { Rural } \\
\text { Respondents } \\
\text { (n) }\end{array}$ & $\%$ \\
\hline Instrumental & 12 & 3.3 & 1 & 0.4 \\
\hline Intrinsic & 138 & 37.8 & 102 & 45.5 \\
\hline Life & 32 & 8.8 & 32 & 14.3 \\
\hline $\begin{array}{l}\text { Moral duties towards } \\
\text { ecosystems }\end{array}$ & 120 & 32.9 & 80 & 35.7 \\
\hline Relational & 332 & 91.0 & 216 & 96.4 \\
\hline $\begin{array}{l}\text { Ecological } \\
\text { resilience }\end{array}$ & 48 & 13.2 & 68 & 30.4 \\
\hline Subsistence, livelihoods & 270 & 74.0 & 179 & 79.9 \\
\hline Mental and physical health & 81 & 22.2 & 53 & 23.7 \\
\hline Identity & 7 & 1.9 & 7 & 3.1 \\
\hline Sense of place & 5 & 1.4 & 13 & 5.8 \\
\hline Cultural heritage & 18 & 4.9 & 9 & 4.0 \\
\hline Sacredness, religious value & 6 & 1.6 & 8 & 3.6 \\
\hline Symbolic value & 6 & 1.6 & 12 & 5.4 \\
\hline Social Cohesion & 1 & 0.3 & 2 & 0.9 \\
\hline General Wellbeing & 32 & 8.8 & 21 & 9.4 \\
\hline Meaningful occupation & 0 & 0.0 & 8 & 3.6 \\
\hline Altruism & 118 & 32.3 & 100 & 44.6 \\
\hline Environmental justice & 1 & 0.3 & 5 & 2.2 \\
\hline Aesthetic & 28 & 7.7 & 26 & 11.6 \\
\hline Recreation, leisure & 10 & 2.7 & 14 & 6.3 \\
\hline Nature-based tourism & 7 & 1.9 & 13 & 5.8 \\
\hline $\begin{array}{l}\text { Education and cognitive } \\
\text { development }\end{array}$ & 5 & 1.4 & 10 & 4.5 \\
\hline
\end{tabular}

